\title{
NOTAS SOBRE LOS ORIGENES DE LA BIBLIOTECA NACIONAL: LAS BIBLIOTECAS DEL ARZOBISPO DE VALENCIA ANTONIO FOLCH DE CARDONA
}

Jesús PRADELLS NADAL Universidad de Alicante 
Domínguez Ortiz terminaba su examen del panorama cultural español de la primera mitad del siglo XVIII con una pregunta clave: “ ¿En qué medida colaboró el Estado al moderado crecimiento intelectual que se advierte en el reinado de los dos primeros borbones?. En cuanto al de Felipe $V$-respondia el autor -en medida muy escasas(1). Las razones expuestas, entre otras, para fundamentar su conclusión eran la falta de legislación y normativas destinadas a mejorar los centros y planes de enseñanza, la ausencia de criterios definidos, por consiguiente la arbitrariedad en la censura eclesiástica y civil, asi como la carencia de iniciativas oficiales para la promoción de instituciones culturales. De hecho, las Academias de la Lengua y de la Historia responden germinalmente a iniciativas privadas que, sólo más tarde, obtendrán el reconocimiento y el patronazgo oficial en 1713 y 1738 respectivamente(2).

En la postguerra, con un saldo elevado de destrucción material, los esfuerzos de la administración borbónica estarán dirigidos en los primeros años a enraizar la remodelación llevada a cabo en el Estado. La organización de las contribuciones de los reinos forales y la aplicación y sucesivos ajustes de la nueva legislación pública en Valencia, Aragón y Cataluña tendrán carácter prioritario. Junto al esfuerzo reconstructor, los intereses dinásticos priman en el conjunto de la política de Felipe $V$ y a ellos se sacrificarán buena parte de los recursos necesarios para el relanzamiento de una política de defensa en el Atlántico por favorecer la de agresión en el Mediterráneo después de los tratados de Utrech. De la misma manera, el racionalismo regalista, muy agudizado en algunos sectores del gobierno hasta 1715, es el instrumento teórico que permite justificar el crecimiento del poder de la corona frente a la Iglesia y las corporaciones estamentales.

Sin embargo, el propio Domínguez Ortiz advierte un paréntesis en la ausencia de promociones oficiales en el campo de la cultura: "Una de las pocas iniciativas oficiales en materia cultural fue la apertura al público de la Biblioteca Real, que con el tiempo se transformaría en la actual Biblioteca Nacional'm(3). No todos los autores contemplan de forma idéntica la perspectiva del siglo que empieza. El hispanista Henry Kamen, al referirse al acontecimiento de la fundación de la Biblioteca lo ve como «el prime- 


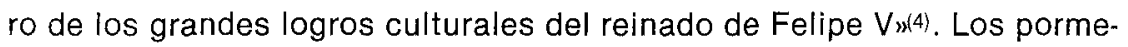
nores de la gestación del proyecto, el estudio de sus protagonistas, las circunstancias en que se llevó a cabo, los propósitos finales que se pretendian alcanzar están todavia insuficientemente estudiados, 10 mismo que el carácter de sus fondos. El problema se sitúa, pues, en el marco de la historia de las instituciones, de la cultura y de sus intrincadas relaciones con el mundo de la política por lo que será necesario realizar investigaciones detalladas que contemplen ambos procesos: el de consolidación del absolutismo monárquico y las formas de su peculiar dirigismo cultural a través de las instituciones promovidas al efecto.

¿De dónde partió la idea?. Parece claro que la iniciativa de crear y abrir al público una biblioteca magna no pudo partir de un monarca a quien, aún de forma involuntaria, el exsecretario de Estado y Despacho de Carlos II, don Antonio de Ubilla, presenta más aficionado a los juegos de cartas que a la lectura, por mucho que en la Biblioteca Nacional se conserven los cuadernos de prácticas latinas del joven monarca(5). Sobre Felipe $V$ actuaron, lógicamente, personajes de particular relieve con la suficiente habilidad para hacerle cobrar entusiasmo por la idea de la fundación, de tal manera que, no sólo no dudó en estampar su real firma, sino que tampoco puso muchos reparos a la hora de dotarla económicamente. Hablar del carácter hipocondriaco de Felipe $V$ es un recurso común, pero en nuestro caso contribuye a explicar las primeras fases de la creación de la Biblioteca Real. La desconfianza personal del rey, que tan bien describe Madame de Maitenon, se traducia en una dependencia constante de los confesores reales que, por su parte, se van a convertír en directores, no sólo de la política eclesiástica, sino también de la "política cultural" si se nos permite esta licencia de expresión.

\subsection{La paternidad del proyecto.}

La idea de crear una biblioteca destinada a tener una función pública cuenta con importantes precedentes entre nuestros humanistas del siglo $X V I$, pero aquí más que de bucear en ellos, y en su fracaso, nos ocuparemos de marcar algunas líneas que contribuyeron a que un proyecto llegase a cuajar en un Real Decreto de constitución así como de señalar algunos 
de los errores comunes que se han ido repitiendo en torno a los orígenes de la Biblioteca Nacional. En este sentido no cabe duda de que fue el $P$. Robinet, tercer confesor de Felipe $V$ en España, el que influyó de forma de. cisiva en el real ánimo para lograr su establecimiento, al presentárselo como una obra que remataría la gloria de su nombre(6).

Las informaciones sobre los entresijos del proyecto no son abundantes y en su mayor parte se trata de reiteraciones con las mismas imprecisiones de fondo, en particular en lo que se refiere a los primeros fondos bibliográficos. En principio, son tres los personajes en torno a los que se considera vino al mundo la feliz idea: el confesor real, el marqués de Villena don Juan Manuel Fernández Pacheco y Zúñiga, y don Melchor de Macanaz. El posible protagonismo de Macanaz es el que mayor difusión ha alcanzado, debido sobre todo a las publicaciones de sus descendientes. Asi, respecto a su participación en la fundación escribe Maldonado Macanaz:

"En unión con el confesor del Rey, el P. Pedro Robinet, jesuita, estableció en el pasillo que comunicaba entonces Palacio con el convento de la Encarnación, la Real Biblioteca, dotada de libros procedentes de las confiscaciones, entre ellos los dos mil volúmenes de la libreria de Fray Antonio Folch de Cardona, Arzobispo de Valencia, que se trajeron de aquella ciudad (7).

Macanaz no era hombre al que la modestia pusiese cortapisas como acreditan sus escritos, pero no es el único en atribuirse la idea pues, el mismo Robinet también la presenta como fruto de su fértil imaginación en carta dirigida al marqués de Mejorada a mediados de 1712. EI P. Nicolás Jesús Belando se encarga de completar el conjunto de posibles progenitores al atribuirla al marqués de Villena(8). Es posible que haya algo de verdad en cada una de las afirmaciones y que el tema saliese a relucir en aquellas tertulias que antes de la guerra tenían lugar en casa de Montellano, o incluso en la que el marqués de Villena tenía en su casa de la plaza de las Descalzas. Es posible también que Macanaz recibiera las intenciones de su amo puesto que las relaciones con la casa de Villena eran clientelares y sus primeras actividades cortesanas tuvieron lugar en las reuniones que los sábados organizaba Montellano y a las que concurrian sobre todo juristas(9). Años después de que la institución se pusiera en marcha el propio Macanaz describe las intenciones que abrigaba: 
"Mi proyecto, era agregarla una imprenta y encargarla la impresión de misales, breviarios y todo cuanto los Gerónimos imprimían en Amberes, así como la de pragmáticas, decretos y Gacetas, concediéndole derecho privativo sobre cuantos libors se imprimiesen para el nuevo mundow(10).

Este proyecto, que rezuma regalismo por los cuatro costados y atiende a las cuestiones fiscales tanto como al control estricto de «todos los libros que se imprimiesen para el Nuevo Mundo", tampoco tuvo desde el punto de vista técnico la acogida que pretendia el fiscal del Consejo de Castilla. Aunque durante buena parte del XVIII y principios del XIX la fundición de caracteres tipográficos va a estar a cargo de la Biblioteca, no es hasta el 19 de junio de 1761 cuando Carlos III ordenó la fundación de la Imprenta Real(11). Pero, desde luego, por lo que no brillaba el proyecto era por su altura intelectual. Macanaz, que prescinde del aspecto monumental de la obra tanto como de profundas razones de indole humanístico o científico, parece nadar sobre consideraciones más pragmáticas. En una estructura gubernamental donde ya se preveía la presencia cada vez más numerosa de juristas profesionales, en detrimento de la privilegiada posición política de la alta aristocracia castellana, que a la larga también se hará extensivo a los colegiales mayores, parece más interesado en crear un organo capaz de centralizar y racionalizar los instrumentos precisos que permitan a los funcionarios establecer un control estricto sobre la información y fundamentar y desarrollar los derechos de la corona frente a su mayor obsesión: las usurpaciones de jurisdicción. Naturalmente, no se trata de minimizar las cualidades intelectuales de Macanaz ya que las pruebas de sus inquietudes están en su copiosísima obra escrita como en el talante de las reformas que tan tenazmente defendio desde la Fiscalía del Consejo(12).

La estatalización y la dirección gubernamental acabarán imponiendo su propia dinámica que, en cierto modo, desvirtua las concepciones que la empujaron a nacer. De hecho, la actividad de las instituciones paragubernamentales estará permanentemente flotando entre dos aguas, la de la ciencia y la del colaboracionismo intelectual para la defensa del orden establecido. En este caso se trata también de un servicio instrumental que facilita la labor de la burocracia en la fundamentación teórica y práctica 
de poder. Misión de dirigismo cultural que no es difícil encuadrar en la paulatina absorción de funciones por parte de un Estado en expansión que ramifica su influencia por caminos cada vez más sutiles hasta erigirse en guardián de la historia y de la lengua mediante instituciones especializadas(13).

A la personalidad de Pierre Robinet sólo hemos podido acercarnos gracias a testimonios fragmentarios que están más relacionados con sus funciones de confesor y los conflictos jurisdiccionales que con sus planteamientos intelectuales. Se han resaltado un cierto galicanismo y la desvinculación de los intereses inmediatos de su orden:

"Robinet no tenía ningún interés, ninguna ambición; no estaba contaminado de ultramontanismo y sólo era jesuita en cuanto era compatible con el honor y la conciencia. Era fundamentalmente hombre de bien; amaba, pues, el bien por el bien mismo, y era tan valiente como discreto. Toda la corte y toda España le amaba, le honraba, tenía confianza en él; no por eso se vanagloriba ni se estimaba en más, y era recto, verídico y enemigo de toda intrigas(14).

De su pasión por la Biblioteca no es posible abrigar ninguna duda, como pone de manifiesto la documentación utilizada por Martín Gaite, pero apenas sabemos nada de su formación intelectual más allá de sus aficiones numismáticas aunque resulta de gran importancia el que como primer bibliotecario mayor contase con Gabriel Alvarez de Toledo, poeta y uno de los más destacados defensores de las teorías atomistas en la última década del siglo XVII(15).

\section{2.-La organización.}

El 29 de diciembre de 1711 aprobaba Felipe $V$ el plan que le habia presentado Robinet para la formación de una biblioteca real(16). Doce días más tarde Grimaldo comunicaba al Condestable de Castilla la decisión de establecer la librería entre el palacion real y el convento de la Encarnación en la antigua calle del Tesoro. Las obras de acondicionamiento fueron encargadas a Teodoro Ardemans y el 12 de marzo se abría primera vez al público. 
Robinet, verdadera alma mater del proyecto, se entregó a él con decisión incluso en los momentos de mayor dureza, provocados por la crisis política que se abre con la muerte de María Luisa y que acabará significando la desgracia de los personajes y ministros más radicales del período de guerra-Ursinos, Orry, Macanaz-aparece «entusiasmado con la idea de perfeccionar la librería, y habló de ello con Tinajero y Grimaldo. Quería sacar de alguna parte el dinero necesario para ampliar sus salas y acabar la fábrica necesaria para unir las existentesw(17). Cuando en febrero de 1715 regreso a Madrid el cardenal del Giudice victorioso en el conflico suscitado por la condena del Pedimento fiscal de los cincuenta y cinco párrafos, la posición del confesor real se hizo insostenible. El 7 de marzo se le comunicaba el fin de su misión en España. En una de las últimas cartas dirigidas a Grimaldo se cuidaba de proporcionar detalles sobre cuestiones relacionadas con la Biblioteca, como los libros pendientes de encuadernación, y su intención de dejar ualgunas cosas curiosas no indignas de tener lugar con las que hay ahoran. El mismo dia en que recibio el pasaporte escribió otra vez a Grimaldo:

"No habiendo tenido respuesta sobre los otros puntos y estando para partir mañana, lo que me ha parecido mejor es confiar al P. Esteban Lecompasseur todo lo que toca a la liberia con algunas alhajas mías y libros que destino a la misma y también las cuentas y papeles concernientes a ellas hasta tanto $S$. M. disponga de todo como fuere de su Real Agradow(18).

El día 11 salía hacia Francia, donde, según Saint-Simon, "vivió muy contento como simple jesuita en Estrasburgo, sin meterse en nadaw(19).

Después de la breve estancia del P. Lecompasseur al frente de los asuntos eclesiásticos, regresó de Roma el P. Guillermo Daubenton, jesuita con un talante radicalmente distinto al del $P$. Robinet. En opinión una vez más del duque de Saint-Simón, especialista en comadreos cortesanos, "Daubenton fue admirablemente elegido. Era un hombre gordito, de rostro placentero, cortés, respetuoso con todos aquellos que tenian algo que perder o que esperar, alerta a todo, muy inteligente y aún más prudente, precabido y hábil. Especialmente atento a conocer el modo de ser íntimo de cada cual y sacar provecho de todo, pero simulando bajo una apariencia 
retraida, desinteresada, apartada de los negocios del mundo y, sobre todo, sencillo e incluso ignorante, una gran sutileza, un espíritu de intriga de los más peligrosos; una falsedad innata y una desmesurada ambición de intervenir y de gobernarlo todow(21). Pero más significativo que la descripción subjetiva del carácter de Daubenton es su íntima vinculación con la Compañía y con la Curia vaticana, pues hasta reintegrarse de nuevo a su cargo de confesor desempeño en Roma el de asistente general de la Compañia y fue miembro destacado en la redacción de la Unigénitus(20). Daubenton se convirtió en el director de la Biblioteca Real y su actividad va a condicionar mucho más que los estatutos de funcionamiento interno. La importancia de los confesores ha sido claramente puesta de relieve por Antonio Mestre al indicar como sus intervenciones tenian un gran peso específico, no sólo en lo concerniente a la dirección de la política religiosa, sino también de la vida intelectual elegian los bibliotecarios reales con las consiguientes posibilidades que tales cargos entrañaban(21).

La dirección que iba a tomar la Biblioteca puede vislumbrarse, en principio, a través de un hecho lo suficientemente significativo. Al quedar vacante el cargo de bibliotecario mayor por la muerte de Gabriel Alvarez de Toledo, uno de los aspirantes a la plaza será el deán de Alicante, Manuel Martí. Su cercanía a los círculos intelectuales filojansenistas de Roma, la amistad con Saenz de Aguirre, Gravina y Enrico Noris, los informes sobre el antijesuitismo del deán que los padres de la Compañía en Alicante proporcionaron a Daubenton, fueron suficiente para desestimar su candidatura. Si a ello se unen sus vinculaciones con el austracismo, y en particular con el duque de Medinaceli, se explica que la decisión fuera adoptada en favor del párroco de San Andrés, Juan Ferreras. El criterio de selección no es circunstancial ni caerá en el olvido, pues años más tarde los mismos planteamientos de rigurosidad y actitud critica defendidos por Gregorio Mayans y Siscar encontrarán un cúmulo insuperable de dificultades(22).

El estatus oficial se lo confirió un Real Decreto de 2 de enero de 1716. No obstante, la primera asignación de rentas habia sido hecha en virtud de R. C. de 14 de diciembre de 1715 sobre "el recargo de dos maravedies en cada libra de tabaco en polvo, hoja y cigarros de todos géneros que se consumieren en los reinos de Aragón, Cataluña y Valenciaw(23), mientras en la de 2 de enero se fijaba en 8.000 pesos anuales sobre el tabaco y naipes 
del reino(24). La distribución de las rentas quedaba fijada de la forma siguiente:

$\begin{array}{lll}\text { Sueldos del personal . . . . } & 4.300 \text { pesos. } \\ \text { Gastos Ordinarios . . . . . . } & 1.200 \text { pesos. } \\ \text { Compra de libros . . . . . . } & 2.000 \text { pesos. }\end{array}$

La ley regulaba también el número de empleados y la cuantia de sus salarios: El bibliotecario mayor recibiría anualmente 1.000 pesos escudos mientras cada uno de los cuatro bibliotecarios recibirian 500, lo mismo que el administrador. Dos ecribientes percibirían 250 mientras el portero y su auxiliar cobrarían 200 y 100 respectivamente. Posteriormente, de las misma manera que los impuestos en los reinos forales tendieron a estabilizarse en cifras constantes, la contribución a la Biblioteca se redujo a la cuota fija de 131.199 reales y 30 maravedies en 22 de julio de 1731(25). Aunque con algunos tropiezos económicos, como la indemnización por concepto de alquiler a las monjas del convento de la Encarnación, por una renta de 7.000 reales desde 1729 (26) no parece que hubiera ningún reajuste de importancia en el volumen de ingresos ni en las normas básicas de funcionamiento.

Las primeras constituciones fueron redactadas por el $P$. Daubenton y comprendía la distribución de obligaciones del personal, la regulación de horarios, el procedimiento para las visitas y préstamos así como otra serie de obligaciones y normas(27). En 1751, don José Fernández Gutiérrez, sustituto de Blas Antonio Nasarre, redactó un proyecto de reforma consecuencia del crecimiento. A decir de Ponce de León, básicamente se trataba de nombrar un asesor para vigilar el exacto cumplimiento de los privilegios de la Biblioteca, tales como la obligación de los impresores de entregar un ejemplar de cada impresión que se hiciese(28). Al mismo tiempo se hacía referencia al ascenso de categoría de los bibliotecarios que pasarían a ser considerados criados de la Real Casa(29). No obstante el plan será desestimado hasta 1761 en que Juan de Santander elaboro nuevas ordenanzas sobre el modelo de las de Fernández. Se estableció un nuevo horario, se prohibía la extracción de libros y manuscritos, la publicación de fondos sin la autorización expresa del bibliotecario mayor y se les asciende a criados de la Real Casa. 
Con los gobiernos ilustrados la Biblioteca recibirá un nuevo impulso que empieza por el cambio de dirección. En 1783 el valenciano Francisco Pérez Bayer sustituía a Juan Manuel de Santander, mientras que en 1793, la época de cerrazón frente a los vientos de la Revolución francesa, se hará cargo el obispo de Albarracín don Pedro Luis Blanco. Los nuevos proyectos de los ilustrados fueron acompañados de un aumento presupuestario decretado por Carlos III y se traducen más en acciones concretas que en declaraciones de principios. El decreto de establecimiento de 1716 no hace en este sentido más declaración sobre los objetivos y motivos que la Real Gana:

"Habiendo resuelto establecer una Biblioteca, y colocarla dentro de mi Real Palacio de Madrid, se ha juntado en ella el mayor número de libros que hasta ahora se ha podido, con algunos manuscritos, varios instrumentos matemáticos, porción de monedas, medallas y otras curiosidades; para cuya subsistencia y manutención....x(30).

En cambio, el decreto de 26 de julio de 1716, se muestra menos parco: "Siendo mi ánimo, desde que mandé erigir la Real Biblioteca, que mis vasallos tengan en ella la erudición y enseñanza que necesitan, a cuyo fin se ha procurado adornarla de todos los libros más exquisitos que se han encontrado....(31).

Con motivo de la aprobación de las nuevas constituciones en 1761, el primer punto del Real Decreto presenta los matices tipicos de la ilustración:

"La Biblioteca, como fundación Real, y una de las más preciosas alhajas de la Corona, de que resulta tanto beneficio y honor al Estado, estará siempre bajo la protección de S. M.;...

El incumplimiento, parece que bastante difundido, del decreto de 26 de julio supuso que, de nuevo, se contemplase la cuestión de los privilegios en 1761 y se diluyesen las posibles dudas:

"De todas las obras, libros, papeles y escritos de cualesquiera clase y por pequeños que sean, que se impriman o reimpriman en los Reynos y dominios de S. M., se deberá entregar un exemplar a la Real Biblioteca..., y a fin de que cesen las dudas, 
que algunos han suscitado voluntariamente para excusarse de la entrada del exemplar de cada libro u obra; se declara ser comprehendidas en dicha obligación no sólo las obras de primera impresión, sino todas las reimpresiones que se hicieran de ellas, aunque sean idénticas,...»

También se prestaba atención a otro privilegio de la Biblioteca referente al derecho de opción y tanteo de las bibliotecas que fueren vendidas por testamentaria. Se regulaba la obligatoriedad de los tasadores de poner en conocimiento del bibliotecario el inventario completo y la necesidad de comunicar con quince días de antelación cualquier venta de este tipo para que la Biblioteca pudiese ejercer su derecho, en conjunto o en la venta al por menor. Pero de la misma manera se acentua el carácter utilitario al transformarla en un archivo paralelo y centralizado:

"Siendo muy conveniente que en la Real Biblioteca se conserven todas las ordenanzas, reglamentos, pragmáticas, cédulas, decretos y demás papeles que de orden de $S$. M. se imprimieren por las Secretarias del Despacho Universal, Consejos y Tribunales de estos Reynos; y habiéndoles comunicado esta resolución que ha tomado S. M., para que los impresores respectivos no puedan escusarse con pretexto alguno de su cumplimiento,..., y deberán acompañar el correspondiente recibo de la Biblioteca, quando presentare a las Secretarías, Consejos, etc. las cuentas de las impresiones que hubieren hecho de su órden".

El tema de los presupuestos queda comprendido en los apartados 6 y 7. Para los gastos ordinarios anuales se consignan 39.356 reales de vellon, pero además se destinan otros cincuenta mil para la compra de libros, manuscritos y medallas distribuidos de la forma siguiente:

$\begin{array}{lll}\text { Libros impresos y manuscritos ... } & 20.000 \text { reales. } \\ \text { Medallas y antigüedades ....... } & 10.000 \text { reales. } \\ \text { Impresiones a cargo de la B. Real . } & 20.000 \text { reales. }\end{array}$

Finalmente el último punto trataba sobre la necesidad de buena presencia y compostura: 
"Tampoco permitirá, que se entre en ella con gorro, cofia, pelo atado, embozo u otro traje indecente o sospechoso, ni mujer aiguna en dias y horas de estudio; pues para ver la Biblioteca, podrán ir en los feriados con permiso del Bibliotecario mayor....s(32).

El tercer hito importante dentro del capítulo de los objetivos de la Biblioteca vino también desde las alturas gubernamentales: "A Jovellanos de debe la aprobación del plan de reforma de las constituciones, que en 1788 cambió notablemente la organización interior de la librería»(33). Se contrataron dos especialistas, uno en lenguas orientales y otro en clásicas que, junto con los seis bibliotecarios que ahora constituían la plantilla debian preparar la publicación de manuscritos.

Será ya en 1802 cuando, por Real Orden de 31 de marzo, se modifiquen de nuevo los estatutos de acuerdo con las propuestas del entonces bibliotecario mayor D. Antonio Vargas, que fuera sucesor de Azara en Roma, y que introducian la primera división por secciones(34).

Como apéndice a estos rasgos generales sobre la organización de la Biblioteca Real en el siglo XVIII, cabría señalar el periplo a que se vió sometida hasta el tercer cuarto del siglo siguiente. En 1809, por orden de José I, sería trasladada al convento de la Trinidad en la calle de Atocha y reorganizada por Juan Antonio Escoiquiz, que a su vez redactó los estatutos de 1813. Su estancia allí fue breve ya que el 1819(35) pasó a ocupar el palacio del Consejo del Almirantazgo, antigua residencia de Grimaldi y Godoy, hasta 1826 en que sufrió un nuevo traslado a la calle Arrieta donde se incorporaron los fondos de la biblioteca de las Cortes y los procedentes de los conventos vacantes. En 1836 dejó de depender de la Casa Real para integrarse en el organigrama del Ministerio de la Gobernación, hasta que se terminaron sus viajes en el actual edificio que comenzó a construirse en 1866(32).

\section{3.-Los fondos iniciales.}

Las referencias a los fondos iniciales de la Biblioteca rara vez aparecen separados de los acontecimientos de la Guerra de Sucesión y se identifican con el tema de las confiscaciones a los disidentes del partido borbónico. Maldonado Macanaz señalaba cómo entre los libros que formaron el primer 
núcleo se encontraban "los dos mil volúmenes de la librería de Fray Antonio Folch de Cardonan. En principio, la afirmación no deja de ser cierta, pero en realidad la biblioteca personal del arzobispo estuvo muy poco tiempo en las estanterías de la Biblioteca Real como se podrá comprobar en las páginas siguientes. Sin embargo, la importancia de las confiscaciones, sobre todo en lo que a Valencia se refiere, no tuvo un reflejo demasiado importante en la formación de la Biblioteca. Kamen, por ejemplo, dice respecto a la cuestión: "Cuando se acordó fundar la Biblioteca Real,..., se decidió que la colección de libros del prelado sirviera de base. Macanaz, por lo tanto, dispuso la transferencia de toda la biblioteca arzobispal a Madrid, según deseos del padre Robinet, quien en 1713 se convirtió en el primer director de la Biblioteca Real. Entre las demás obras incorporadas a la biblioteca habia una magnífica colección de libros que Felipe $V$ compró en Francia, así como miles de volúmenes confiscados en los estantes de rebeldes ausentes en campo enemigor(36).

Todas estas apreciaciones requieren matizaciones de relieve en lo que se refiere a la composición de los fondos y su origen. La adquisición de libros va a tener varias vías: las colecciones que ya existían en la Casa Real, las procedentes de confiscaciones, las compras y las donaciones. Nos ocuparemos con mayor amplitud del tema de las confiscaciones donde se incluirian esos miles de volúmenes y las bibliotecas de Folch de Cardona. Una de las colecciones que sirvieron de base fue la conocida como Biblioteca de la Reina Madre existente ya en 1637 y que estuvo instalada, hasta el incendio, en la Torre del antiguo Alcázar de los Austrias. La componian manuscritos e impresos dispuestos en ochenta estanterías que totalizaban 2.234 volúmenes(37). A ellos se unirán los comprados por Felipe $V$ en Francia.

En virtud de los privilegios de la Biblioteca, a lo largo de los años se fueron incorporando, además de los libros impresos en España, diversas colecciones procedentes generalmente de testamentarias. En 17.13 se hizo la primera adquisición de importancia, la biblioteca del duque de Medinaceli, muerto en extrañas circunstancias en Pamplona dos años antes, por 18.000 reales, además de una importante colección de monedas y medallas en cuya clasificación había intervenido el deán Martí. Constan 184 monedas de oro, 2.641 de plata y 6.495 de bronce estimadas en 26.852 
reales(38). En 1724 se adquiere la biblioteca de don Ignacio Suárez de Guevara y obras de medicina que fueron del Dr. Salcedo por valor de 1.500 reales, ya en 1740. Otras tres colecciones de calidad extraordinaria pasarían a formar parte de la Biblioteca durante los reinados de Fernando VI y Carlos III: la del conde de Miranda en 1757, la del cardenal Arquinto, adquirida en Roma en 1760 por orden de Carlos III, y la de don Andrés González embargada por "ab intestato" en 1743. También en 1764 tuvo lugar una compra en el extranjero, se trata de parte de los fondos del colegio Luis el Grande de París. Las bibliotecas de Juan de Chindurza, la del que fuera embajador en París, Ignacio Muzquiz, en 1823; la del diputado a Cortes, Navarro y otras, pasarían al patrimonio de la Biblioteca como las de Juan Nicolás Bölh de Faber, Benito Maestre, Agustín Durán, etc.

En cuanto a los libros que procedian de confiscaciones, su número es difícil de precisar sin un detallado análisis de los registros de la Biblioteca aunque se puede hacer alguna aproximación. Ciertamente fueron miles los libros confiscados a lo largo de la guerra y probablemente muchos más los que cambiaron de mano con motivo de los saqueos de los imperiales y de los borbónicos. A modo de ejemplo, y por aparecer expresamente mencionado el objeto de este artículo, reproducimos una viva descripción del ambiente que reinaba en Alicante en el verano de 1706 con motivo de la entrada de los aliados:

"Las Casas y Conventos de la Ciudad fueron del todo saqueados. Duró el saqueo más de un mes. $Y$ entonzes de quatro, $y$ seis leguas distantes venian de los Lugares con bagages á cargar ropas, libros, alajas, y todo lo que compraban á infimo precio á los ingleses, á quienes solicitaban que arrancassen Visagras de las ventanas, Zerraduras de las puertas, y Armarios, ofreciendo comprar cuanto sacassen. De todo el Reyno vinieron como á una feria. Las puertas, ventanas y camas de[l] campo servían de leña a los enemigos.

Quedó la Ciudad hecha un esqueleto. Las Casas arruinadas, sin alajas, sin puertas, sin ventanas. Las Sacristias de las Casas de Religión sin calizes, sin ornamentos. Sus Librerias sin libros: todo movía compassión. Menos algunas pocas casas, en que habitaban los Ofiziales, y Cabos, y algunos del partido Imperial, todas estaban maltrechas»(39). 
Casos similares debieron producirse en Valencia, Játiva, Sagunto, Orihuela y otras muchas ciudades en uno u otro momento de la contienda. Sin embargo, aunque en algunos textos se haga referencia a los miles de volúmenes que fueron a parar a las estanterias de la Biblioteca Real, otros dan una imagen diametralmente distinta. Rodríguez Marín, buen conocedor de los entresijos de la Biblioteca Nacional, en su breve estudio sobre los primeros fondos hace expresa mención de tan sólo 224 volúmenes que en 1720 se incorporaron a ella procedentes de la Depositaría General de Bienes Confis$\operatorname{cados}^{(40)}$. A pesar de ser las confiscaciones una de las cuestiones a las que todo autor que trata el periodo dedica indefectiblemente unas lineas, poco es lo que se conoce en profundidad sobre su verdadero alcance, los afectados, su destino que tuvieron y si se volvieron o no a sus antiguos propieta-

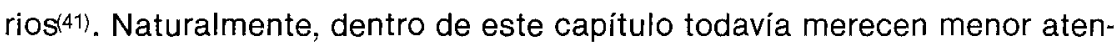
ción los bienes muebles, aspecto por el que también se preocuparon los funcionarios reales. En unas "Breves instrucciones... «42) se recomendaba aplicar como mercedes patrimonios enteros como forma de que los propios interesados se ocuparan de descubrir cualesquiera formas de renta. Los bienes muebles recibian una atención particular debido precisamente a la dificultad para su determinación y control.

Los acontecimientos ocurridos en Valencia entre el 16 de diciembre de 1705 y el 8 de mayo de 1707, la represión subsiguiente a la entrada de los soldados borbónicos y las prevenciones que el intento de desembarco de 1710 volvieron a inflamar, los exilios, los motines, en definitiva, la guerra permiten suponer que las pérdidas materiales fueron cuantiosas y que patrimonios enteros quedaron afectados de forma irreparable: muebles, cuadros, tapices, tallas, libros y menajería en general aparecen consignados en las relaciones oficiales. En menor medida, por las Iógicas prevenciones de sus poseedores resultarían dañados los objetos de mayor valor intrínseco y fácilmente convertibles en caso de necesidad como las joyas y los objetos de oro y plata(43). Parte de estos bienes pasarán a la corona, pero es de suponer que en mayor proporción pasarian a manos de particulares más necesitados o de forma más o menos legal a los mismos funcionarios. Conocemos algunos casos aislados gracias a la documentación del A. H. N.. En los primeros meses de 1710 Grimaldo comisionaba a Pérez de la Puente, el superintendente de rentas reales de Valencia, para 
que se encargara de recuperar las alhajas y bienes «que estuviesen en poder del Presidente (de la Chancillería); Larreateguí Colón, los ministros y demás personas sin excepción». De la Puente cumplió con rapidez, aunque por encuesta a cada uno de los funcionarios, y el 29 de abril enviaba una larga lista de los bienes que había conseguido localizar y que, en parte, fueron entregados al Depositario General de Bienes Confiscados, don Francisco Miguel Danvila(44).

Lamentablemente la relación enviada por el superintendente no consiste sino en una enumeración, con una breve descripción, de los artículos reunidos, sin tasación alguna, donde hay desde cuadros, muebles de artesania con maderas preciosas, tapices y objetos de uso cotidiano en muy diferentes estados de consevación. Larreategui era uno de los que mayor número de esta clase de bienes habia acumulado, pues, según su propia declaración, tenía cincuenta y un lienzos, dieciocho tapices y una buena cantidad de muebles suntuosos que no podian proceder sino de los palacios y casas pudientes de Valencia. Pero nos merecen especial atención las noticias acerca de algunas librerías, su composición y procedencia. El presidente de la Chancillería «declaró tener pero no entregó... un estante de librería de madera dado de color encarnado con treinta y dos cajones y en ellos quinientos quince libros [de] diferentes autores de Jurisprudencia que proceden del secuestro de don Cristóbal Mercader,(45). Además habia recogido "ciento tres libros, siete de ellos de folio entero", entre los que figuraban los Anales de Zurita y "los demás de usos y diferentes historias y varias lenguas".

Rodrigo Cepeda, que como miembro de la Chancilleria formo comisión con Macanaz, Rodrigo Caballero y el propio de la Puente en 1707 para la reforma monetaria y luego sería el encargado de la administración del valimiento real sobre los bienes confiscados(46), mostró también ciertas tendencias acaparadoras. Aunque en este caso ignoramos su procedencia concreta, conocemos en cambio la relación de algunos autores, y por la preponderancia de juristas se puede pensar en algún funcionario de la Audiencia. Se nombran ocho tomos de derecho civil y canónico, las obras de Juan del Castillo, de Solórzano, del P. Molina, de Valerón, de Velasco-De ludice perfecto-cuatro tomos de Solórzano, dos de Cortiada, dos de Argelio; las obras del valenciano Matheu, las de Leotardo, 
Cancerio, Guirba, Merlino, Carleval, La Rẹg, Postios García, Suelvez, Bobadilla, Amato, Villa Diego, Silva, Valero, Samara, Torreblanca; tres tomos de Mastrillo, dos de Fontenella, uno de Paz, uno de Lazar [?], uno de Mendo, Escobar, Fabroso, las obras de Escopia y Manuel Tesauro, el autor de "ll canochiale aristotelico". También aparecen explicitamente una Historia Pontifical, las obras de la madre Agreda, y Las Guerras de Francia junto a "otros veinte tomos entre grandes y pequeños de diferentes asuntos».

Otro oidor, don Dionisio Rogerio se procuró igualmente una biblioteca de consideración compuesta por «quatrocientos noventa y cinco libros de Jurisprudencia, y otras facultades entre grandes y pequeños que de ellos la mayor parte de mano escripto y casi todos troncados que eran del Dr. Patricio Oller». También se procuró otra, que perteneció al Dr. Micó, con 433 volúmenes igua!mente de jurisprudencia.

Como parece desprenderse de estos casos, no fueron muchos los libros, en relación con los recogidos, que fueron a parar a la Biblioteca Real. Tenemos noticias de un caso parecido en Orihuela, desde donde Gregorio Bádenes, que había sido asesor del gobernador marqués de Rafal y que permaneció en el partido borbónico, escribia a Grimaldo a mediados de 1708. Ahora, como delegado de Macanaz para las confiscaciones de esa ciudad, pedía 2.000 pesos para saldar las cuantiosas pérdidas que habia sufrido y una cantidad porcentual de las rentas que administraba por no haberle sido asignado sueldo alguno. Finalmente añadia:

"...suplico a V. M. merezca la honrra de aprobar la gracia que me hizo el Obispo de Cartagena D. Luis Belluga, siendo Virrey de Valencia, de la librería que se confiscó a D. Joseph Roca, que según el Arancel de los libros que están inventariados, 10 más que pueden valer son tres mil Rls. de vellón; y estoy usando de dhos. libros, por no tener otros para el despacho, por haber perdido mi librería, con el menaje de mi casa, lo que motivó al Virrey $y$ al Administrador que entonces era, me encargara...n(47).

En definitiva, muchos fueron los libros que cambiaron de dueño en los avatares de la guerra y tan sólo una pequeña parte pasó a manos de los funcionarios borbónicos, y en muchos casos allí continuaron sin que se 
cumpliera otra de las sugerencias expuestas por Macanaz, en su Testamento Político sobre la Biblioteca Real:

«...pues a mi instancia resolvió S. M. fundarla, dejando a mi cuidado el recoger en ella multitud de medianas librerias que dejaron abandonadas los que todo lo dejaron por seguir a los enemigos»(48).

\section{Il.-Folch de Cardona.}

Folch de Cardona es otro de esos personajes que no han tenido la fortuna de encontrar algún historiador, o apologeta, que recuperase su figura del limbo de la historiografía. A pesar de ser considerada como una de las figuras más relevantes de la Valencia del setecientos, debido a su alta posición jerárquica y a su propia personalidad, continúa siendo prácticamente un desconocido. No son muchas las noticias que tenemos sobre él durante el período valenciano que no estén relacionadas de manera directa con la Guerra de Sucesión y su choque con Macanaz por la actuación regalista del ministro en Játiva y, en muchos aspectos, es improbable que se encuentre la información necesaria(49).

Las referencias habituales, mediante uno u otro conducto, proceden básicamente de Ortí que, aunque borbónico, por su pertenencia al estamento eclesiástico, va a estar inmerso en la oposición a la politica regalista del gobierno y a los cambios introducidos por las armas en los modelos tradicionales de la vida valenciana. Miñana, cuyo De Bello Rustico Valentino termina en 1707, apenas si se ocupa de las controversias eclesiásticas y casi nada de Folch de Cardona. Si nos acercamos al mundo de los historiadores o cronistas no valencianos es obligada la mención del sardo Vicente Baccallar y Sanna, marqués de San Felipe, que vitupera escarnecidamente al arzobispo, sobre todo desde que mudó de partido en 1710, hasta el punto de atribuir su muerte a una hidropesía provocada por la contrariedad que le produjo que no prosperasen sus continuas conspiraciones desde Viena(50). Eso por no hablar del propio Macanaz, pues bien se pueden imaginar los juicios que formó sobre el aleve del prelado. A partir de ahí, con excepción de interesantes aportaciones documentales de Carmen Martín Gaite y Pérez Aparicio, casi todo son meras repeticiones. 
Sobre la trayectoria personal de Folch, el continuador de la obra de Ximeno, Justo Pastor Fuster, nos ofrece una síntesis con algunos datos no muy conocidos sobre el arzobispo valenciano(51). Hijo del Almirante de Aragón, don Felipe Folch de Cardona, y de "una señora noble valenciana", nació en Valencia el 9 de diciembre de 1657(52). Educado en Ondara hasta la edad de quince años se trasladó a la corte a la muerte de su padre. Siguió primeramente la carrera de las armas y participo como capitán de infanteria en las campañas de Portugal y en Galicia. Como su paisano Borja, aunque probablemente de forma más prosaica, cambió la espada por los hábitos e ingresó en el convento de franciscanos observantes de $\mathrm{Pa}$ lencia. No tardaria mucho en ser elegido por su Provincia de Castilla la Vieja para seguir estudios en el Colegio Mayor de San Pedro y San Pablo de Alcalá de Henares, donde cursó teología y filosofía. Desde entonces, comienza una rápida carrera de ascensos jerárgicos: Jubilado y Guardián de los conventos de Palencia y Avila, Provincial y Vicecomisario General de la Familia Ultramontana desde 2 de febrero de 1692, elección que confirmó Inocencio XII en bula de 28 de julio. El 24 de marzo recibe el nombramiento como Comisario General de Indias, empleos que dejaría para tomar posesión del arzobispado valenciano para el que habia sido propuesto por Carlos 11 y confirmado por bula del 3 de febrero de 1699. El 3 de junio de 1700 tomó posesión por poderes y el 10 de octubre hacia su entrada oficial en Valencia(53).

Se ha señalado cómo el problema fundamental a que tuvo que hacer frente en la archidiócesis valenciana fue el de la Guerra de Sucesión, y cómo su actitud en los primeros años resultó ser de suma importancia para el desarrollo de los acontecimientos(54). Ciertamente la interpretación de la Guerra de Sucesión es un problema complejo, particularmente en la Corona de Aragón, que difícilmente se puede reducir a una categorización jerarquizada de causas y, en menor grado todavía, primando un concepto como el neoforalismo por encima de una rígida estructura señorial, en el caso valenciano, base de la intervención de la población campesina en la guerra. Los planteamientos maniqueos, tan abundantes en lo que se refiere a la Guerra de Sucesión, deben ir dejando paso a perspectivas más globalizadoras que abarquen las realidades económicas, sociales, politicas y de las mentalidades por encima de cualquier tipo de presupuestos apriorísticos, 
pues, como señala Kamen, los «temas de centralismo y el federalismo carecen básicamente de interés frente a las opciones reales de los estados perifèricos de España, en los que los problemas del orden social interno y de la contracción económica revestían un carácter mucho más crucial»(55).

La participación del clero valenciano en la guerra estuvo, en general, identificada con la postura adoptada por su pueblo, pero también, desde 1705, por los condicionamientos de pertenencia a un determinado estatus en la jerarquia social así como, también, a su integración corporativa a un estamento como el clerical con intereses y posturas definidas. Los factores de religiosidad no fueron, en realidad, más que otra de las armas ideológicas a utilizar por ambos bandos(56).

Respecto a la trayectoria de Folch durante la Guerra se han distinguido tres períodos(57). El primero, comprendido entre 1700 y 1705 , en que Folch mantiene una actitud de reserva frente a las crecientes manifestaciones proimperiales de miembros del clero, hasta el extremo de que el virrey Villagarcia se sintió obligado a tomar la iniciativa mediante la amonestación o el castigo con breves periodos de destierro a aquellos elementos más destacados por su proselitismo en favor del Archiduque. Todavia en el verano de 1704, en que se produjo el primer desembarco inglés en Altea, Villagarcia escribia a la corte para que, sin embargo de que el arzobispo le habia ofrecido su colaboración, se le recordaran al prelado sus obligaciones frente a los disidentes(58).

Al parecer, lo que determinó el cambio en la fría actitud del arzobispo se produjo en agosto de 1705, tras la conquista de Denia, en que empezó a formar parte de las juntas de gobierno donde defendería posturas de mayor dureza que el propio virrey. Folch, por su parte, escribirá en diversas ocasiones a la corte explicando la comprometida situación militar y la necesidad de recibir auxilio de tropas con urgencia. Entre tanto contribuyó con donativos, que parecen siempre cortos en la Secretaría de Guerra que presidía Grimaldo; castiga disidentes como el canónigo Gavilá, y sus dictámenes en la Junta recuerdan más a D'Asfeldt que a un eclesiástico, por lo que se podría integrar en el grupo de obispos guerreadores al viejo uso junto a Belluga y el de Calahorra.

Radical apoyo a la dinastía de los Borbones que contrasta con su posterior defección en 1710 a las filas del Archiduque Carlos. Las razones de 
este doble viraje se han intentado explicar con distintos argumentos. Pérez Aparicio parece inclinarse más por las razones que consideran su oportunidad personal y aspiraciones frustradas. En el caso de 1705 considera que:

«...cabria pensar en la posibilidad de que su paso a la causa borbónica se debiera a una decisión tomada por razones oportunistas y que su actitud intransigente como borbónico tuviera como finalidad el tratar de borrar las posibles sospechas que su trayectoria anterior le hacian acreedory(59).

Además se refiere a "un argumento que apenas ha sido utilizado por la historiografía tradicional como explicación de la actitud de Folch de Cardona y según el cual el arzobispo adoptó el partido borbónico tras la rendición de Valencia a las tropas austracistas el 16 de diciembre de 1705, debido a que el Archiduque no tuvo en cuenta sus aspiraciones al virreynato y nombró en su lugar al conde de Cardona. A propósito de ambas personalidades cabe efectivamente pensar en la posibilidad de un enfrentamiento personal por cuestiones familiares, ya que ambos lievaban el mismo apellidow60). Sin embargo, este tipo de argumentos de la historiografía tradicional, son efectivamente asi, tradicionales, y fue utilizado también por sus detractores(61). Pero, incluso cabría decir que Folch de Cardona no abrazó la causa borbónica con tan peculiar ardor después de la caida de Valencia, sino antes. Según la correspondencia que se conserva en el A. H. N. se pone de manifiesto con claridad la cronologia del cambio. El 25 de agosto escribía Villagarcia a Grimaldo:

"...continuando estos naturales en su fidelidad, pues en medio de la felonía de unos pocos, en la ocasión sea [sic] conocido la lealtad de muchos repitiendo a V. S. ser muy digna de la RI. Gratitud la fineza de estos, Comunes y Nobleza de los pueblos del Reyno menos los ynfectos que no son muchos...

El clero esta vien siendo así, que no sólo solía ser del buen sentir pero esta transmutación puede atribuirse a las persuaciones de este Arzobispo Prelado mio»(62).

El 2 de octubre era el propio arzobispo el que escribia a Grimaldo sobre las medidas que se debían tomar para la recuperación de Vinaroz: 
"Sabida la perdición de Vinaroz... me hallé en la Junta de ministros que tuvo su Excelencia para deliberar lo que devia hacer en este casso y fui de parecer... intentasen la recuperación de este lugar, primero por los medios de la blandura y la suavidad, y que si estos no bastasen, usasen de todos los extremos de el rigor, talándoseles sus campos, quemándoles las viñas y olivos, y todos los barcos que tendrian en la plaia, a que está reducido el caudal de aquellos vecinos, y últimamente diesen fuego a las casas del arrabal que es lo principal de el lugar y más numeroso de él, pues lo que llaman Villavieja, que es la que está murada, es la parte más interior de su vecindad, y no tengo por posible que, al ver los de dentro arder sus vienes, casas y parientes de fuera dejasen de rendirse, lo que sería infinitamente importante pues no solo se conseguía la restauración y castigo tan justo de aquel lugar, sino el escarmiento y seguridad de los demas»(63).

El 27 del mismo mes de octubre escribía de nuevo al secretario de Guerra y Estado sobre la insuficiente defensa de la ciudad y el aumento del descontento popular en la capital, pues a su entender, Valencia caería "no ante la fuerza del enemigo, sino ante los sediciosos del interior al que son propensas estas gentesw(64). Tan sólo quince dias antes de la entrada de los austracistas repetía lo delicado de la situación, pedía refuerzos militares y se excusaba de las quejas que le habia hecho Grimaldo sobre su donativo de 1.000 libras alegando no haber cobrado las rentas desde hacia dos años(65).

A la vista de esta documentación, parece dudoso que fueran las razones puramente personales y familiares las que hicieran inclinarse al arzobispo por el partido de Felipe V. Pero, igualmente su evolución en los años que median hasta 1710 contribuyen a aclarar su actitud de compromiso con la aristocracia y la defensa de los privilegios del estamento eclesiástico más que los motivos de pura bandería política. En este sentido es posible que, después de la batalla de Almansa, las arbitrariedades cometidas tras la anulación de la legislación foral, con el ambiente de disconformidad que generaron, se unieran al que va a ser punto esencial de su disconformidad con el nuevo régimen: el recorte de privilegios. 
Cuando entraron los austracistas en la ciudad, el palacio arzobispal se convirtió-según Pérez-en el centro de operaciones de los borbónicos. Si consideramos la descripción de Miñana, parece más indicado decir que se convirtió en refugio ante el ambiente de motín antinobiliario que se produjo. De hecho, el 28 de diciembre, hombres armados intentaron su asalto. Desde su óptica particular, donde se contraponen hombres honrados y canalla desenfrenada, Miñana cuenta cómo sus ocupantes se distribuyeron después del incidente por los conventos de frailes, hasta que algunos de ellos obtuvieron permiso para abandonar Valencia(66).

La ausencia de la diócesis hubiese supuesto la pérdida de la capacidad legal para continuar rigiéndola por lo que Folch regresó para instalarse en un pueblo fronterizo, mientras en Valencia se abrian una serie de conflictos con marcado carácter social y político junto a otros que afectaban a la delimitación de las competencias jurisdiccionales de la Corona y la Iglesia. El arzobispo había dejado como Vicario General a Francisco Antonio Sallent que falleció poco después. El nuevo nombramiento de cabildo recayó en don Luis Rocamora, penitenciario de la catedral, que no fue ratificado ni recusado por Folch por entonces ya en Biar. «Este pueblo,..., lo gobernó a su vuelta de Castilla, el Arzobispo de Valencia, porque sus habitantes eran adictos al Rey y porque estando en su diócesis, podía regir desde él con derechos el Arzobispado. En este tiempo mandó reparar a sus expensas los muros de la fortaleza próxima al pueblo; los que por efecto de la vejez estaban por muchas partes arruinados y mandó traer cuatro cañones que había comprado en Alicante; en este pueblo permaneció mucho tiempo, hasta que recrudecida la guerra en la provincia, temeroso y sin saber que partido tomar en sus asuntos, decidió abandonar el pueblo y volverse a Castilla»(67).

Las relaciones entre la Corona y la Iglesia presentaron un esquema similar durante la etapa austracista y en los primeros años de la restauración borbónica en Valencia. En ambos casos, la primera tratará de asegurarse un clero si no adepto, al menos dócil. Las necesidades económicas tuvieron un papel importante. En el caso de los aliados una de las aspiraciones fundamentales será la consecución de los ingresos de la Bula de Cruzada, como posteriormente para el partido contrario lo serán los recursos de las diócesis vacantes, aspiraciones que exigian un amplio margen 
de colaboración por parte de la jerarquia eclesiástica. Naturalmente, el aparato de la Iglesia va a presentar una gran resistencia a todo aquello que signifique una merma de sus privilegios. Orti explica detalladamente los conflictos que se suscitaron entre ambos poderes a la muerte de Sallent. El nombramiento de Rocamora en febrero de 1706 parece responder más a su sólida oposición a toda intromisión del poder civil o militar en el terreno jurídicamente reservado a los eclesiásticos, que a su borbonismo. Rocamora, de carácter rígido, y reacio a cualquier claudicación en materia de jurisdicción, hasta el punto de que tampoco se mostrará dispuesto a hacer concesiones a los borbónicos años más tarde, entró en conflicto frontal con la Audiencia austracista a raíz de la detención y deportación a BarceIona de un grupo de eclesiásticos en agosto de 1706. Al anatema lanzado por Rocamora contra el Dr. Terrasa, funcionario que ejecutó las detenciones, siguió la anulación de su nombramiento por el cabildo pretextando la presencia de Folch en la diócesis. Por su oposición a la politica regalista de los austracistas, donde se imbricaba también el espinoso asunto de las confiscaciones a eclesiásticos, Rocamora fue desterrado en septiembre poco antes de que el Archiduque arribara a Valencia después del fracaso de su primera ofensiva contra Madrid. El Cabildo procedió, en consecuencia a otro nombramiento de vicario interino del que resultó electo Pedro Llacer, que de inmediato dio muestras de una mayor capacidad negociadora con las autoridades pero, también con importantes renuencias en cuanto a los puntos de competencias jurisdiccionales ${ }^{(68)}$.

Las desavenencias con la administración borbónica van a tener bases muy parecidas, por no decir idénticas. En esencia se trata de la contradicción entre las aspiraciones que mueven la política eclesiástica de la Corona frente a la defensa de la inmunidad y la exención tributaria del clero69). El decreto de 29 de junio de 1707 que disponia la transformación en Audiencia de la Chancillería para que, en adelante, se rigiera en todo por las leyes castellanas excluía expresamente "las controversias y puntos de jurisdicción eclesiástica y modo de tratarla, que en esto se ha de observar la práctica y estilo que hubiere habido hasta aqui, en consecuencia de las concordias ajustadas con la Santa Sede Apostólica, en que se debe variarm(70). Se había reconocido, por otra parte, que la Iglesia no podía quedar, por los crimenes de sus miembros, incursa en el delito de rebelión. 
«El edicto de nueva planta-dice Mariano Peset-se desarrollaría por la real cédula de 7 de septiembre de 1707, para respetar la situación de la iglesia, recortando en lo posible algunos de sus privilegios. También parecía mejor esta forma de resolver los conflictos, que podia ser favorable al monarcas(71).

El malestar del clero valenciano era evidente, como demuestran las numerosas detenciones llevadas a cabo por la autoridad eclesiástica y que tan minuciosamente recoge Orti en su Diario. Tensiones que obedecian al ambiguo reconocimiento que Clemente XI hizo de Carlos III como Rey Católico, por los cambios introducidos en la vida valenciana y a razones de índole económica, "pues el estado eclesiástico se vió afectado por donativos e impuestosm(72). La represión de la disidencia política y del malestar que se suscita en el clero se convirtieron también en una pieza clave. El Vicario Rocamora, reincorporado a su puesto, no dudó en llevar a cabo esta función(73) hasta que el inquisidor don Isidro Valmaseda, con el correspondiente Brebe, inició los procedimientos en igual sentido. Represión que en cierto modo oculta y confunde problemas de defensa de privilegios estamentales y divergencias políticas de carácter más general, como se pondrá de relieve con claridad en el caso de Játiva.

Macanaz, como juez de confiscaciones y encargado de la reconstrucción de San Felipe, amparado en una interpretación donde se conjugaban las instrucciones recibidas como confiscador y las expuestas en el decreto de reedificación, procedió a intervenir las propiedades del clero setabense dándoles el mismo tratamiento que a los seglares. El 5 de diciembre publicaba Macanaz el bando en que se emplazaba a los antiguos habitantes a justificar su fidelidad, propiedades y rentas y, en el caso de los religiosos y religiosas, también los beneficios, capellanias y otros derechos privilegios clericales(74).

Las protestas a la corte fueron inmediatas. El Nuncio solicitará repetidamente la inmediata revocación del bando por considerarlo ofensivo a la inmunidad eclesiástica". También el Consejo de Castilla intervino con rapidez a través de su fiscal Curiel, desaprobando la conducta de Macanaz y le conminaba a sujetarse a las directrices del presidente de la Chancilleria. El ministro, lejos de doblegarse, buscará apoyo en la autoridad de D'Asfeld, ya que en realidad, las medidas adoptadas estaban en 
consonancia con las líneas trazadas por el equipo reformista francés de la corte. El primero de enero de 1708 Grimaldo le comunicaba la concesión de una merced de 1.500 escudos sobre los bienes de San Felipe. El Consejo de Castilla, con Ronquillo a la cabeza, presiona en el sentido de la normativa legal a la vez que le recordaba la resolución del rey sobre que los casos de dependencia eclesiástica los resolviese el arzobispo. Pero, además de que Macanaz discrepaba en lo que debian considerarse temas de indole eclesiástica, es cierto también que se había puesto gran cuidado en imponer las directrices a las que debía sujetarse el arzobispo.

En septiembre de 1708 se reunió una junta para tratar especialmente del caso de Macanaz donde resultaron condenados sus procedimientos mientras Macanaz se defendia al mantener que no hacia otra cosa que salvaguardar los derechos de la Corona. Se propuso la anulación de todos los procesos, su traslado a la curia arzobispal y la devolución de los bienes "sin litigio ni figura de juicio», así como se mostraba de acuerdo con el deseo del arzobispo de remover al ministro de su cargo.

En este estado de la cuestión, el inicio de la intervención de Robinet, primero moderada y más tarde en completa defensa de Macanaz, resulto decisiva a la par que la división en el seno del gobierno se hacía cada vez más profunda.

En noviembre D'Asfeld informaba de que si las dependencias de San Felipe no avanzaban con mayor rapidez se debía exclusivamente al obstruccionismo del arzobispo y la curia. Grimaldo se situa, prudentemente, con actitudes condicionales entre ambos bandos al responder que de ser verdad, se trataría de una usurpación de las regalias y de una conducta atentatoria contra el derecho común pues, «aunque sean eclesiásticos los reos deven también por razon de tierra y bienes raizes ser convenzidos delante del juex seglar, sin poder entrometerse en dichas causas los eclesiáticos y todo lo que contra esto obrare el Arzobispo seria notoria usurpación de la jurisdicción realı(75).

Los problemas planteados en Játiva constituyen, pues, el centro neurálgico del enfrentamiento entre las líneas políticas representadas en el gobierno y los intereses corporativos del clero. A lo largo de 1708 y los primeros meses de 1709 continuarán los recursos a la corte, las amenazas de entredicho, la resistencia al abandono de las posiciones conquistadas, 
los ataques personales y hasta un intento de procesar militarmente a Folch de Cardona por parte de Macanaz que se cuida de permanecer en la sombra(85). A partir de abril las circunstancias generales favorecerán al ministro de Hellín. En ese mes estalla la crisis entre la corte y la curia romana y el regalismo de la corona se radicaliza. Aunque sin el apoyo de D'Asfeld, que en junio fue reclamado por Luis XIV, Macanaz contó con la intervención sin reservas del $P$. Robinet.que el 15 de julio lo presenta como víctima de una coalición del Consejo, la Chancilería y el arzobispo. Debilitada su posición desde la expulsión del nuncio Zondadori, Folch de Cardona recurrió a su última baza en diciembre publicando la excomunión de Macanaz. El ministro elevó un memorial donde se acusaba al prelado de usurpar la jurisdicción del rey, lo calificaba de contrario al monarca y de colaborador con el enemigoi77).

Robinet, que según sus propias declaraciones contaba con la opinión favorable del Inquisidor General y del obispo Solís, abogó con renovado vigor por la absolución del funcionario. Al ser interceptadas algunas cartas cifradas del arzobispo con los austracistas de Barcelona, las sospechas contra Folch parecieron confirmarse. El prelado valenciano aprovechó entonces la coyuntura propicia que significaba la entrada en Madrid de las tropas imperiales y el 26 de septiembre se encontraba entre los que besaron la mano del Archiduque en la Quinta de Aguilar, pasando luego a for. mar parte del Consejo de Gabinete(78).

En definitiva, las motivaciones de tipo personal son elementos que se integran en unas realidades más complejas. Cuando empiezan a producirse las primeras manifestaciones en favor de la sucesión austriaca en Valencia, y hasta el verano de 1705, las autoridades no les dieron una importancia desmesurada por la sencilla razón de que el mismo virrey (argumento que resulta conocido también en estos últimos años) las consideraba como las bocanadas finales de la Casa de Austria en España, tanto más cuando la decisiva intervención militar aliada, por causas de técnica y estrategia militar, no pudo desarrollarse hasta el verano de 1705(79). Frente a las consideraciones de orden pesonal, parece más lógico pensar que la forma de revuelta que caracterizó la participación campesina y popular situó automáticamente a la mayor parte de la aristocracia en el bando borbónico, entre otros motivos porque era el poder establecido, y esa inercia 
no puede despreciarse. Tampoco se puede ignorar el abolengo aristocrático del arzobispo, que, en principio y salvo demostracion en contrario, consideramos como un ejemplar castellanizado profundamente. Como la mayor parte de la nobleza valenciana, difícilmente pudo mostrarse dispuesto a apoyar un partido que, al menos en su propaganda y en la actitud de Baset, se basaba en la anulación de los fundamentos del sistema señorial. La dirección que se imprimió más adelante desde el gobierno hacia la centralización, abrogando las constituciones forales y algunos de los privilegios corporativos y estamentales de los eclesiásticos, junto con los sentimientos personales de sentirse acosado por un ministrillo que se le puso por montera, el intento de proceso militar, la crisis de 1709 , la desautorización de que fue objeto por el confesor real, desembocaron finalmente en su defección. En este contexto es más comprensible la afirmación del autor de los Reparos críticos cuando afirma que el cambio de partido de Folch de Cardona se debió «al dolor ante los ataques a la inmunidad eclesiásticas(80). Si la solución fue extrema, probablemente se debió a las circunstancias, pues un caso que presenta cierta similitud es el del obispo de Cartagena don Luis Belluga que, desde la exaltación desaforada de la figura de Felipe $V$, pasa a reclutar ejércitos y dirigir campañas, para poco después, como consecuencia de las contribuciones exigidas al clero, escribir su memorial antirregalista.

Acontecimientos posteriores parecen confirmar todavía más esta apreciación, ya que Jacinto Ortí, cuyo borbonismo estaba fuera de toda duda, «por haber defendido varonilmente la inmunidad eclesiástica, fue desterrado el 7 de julio de 1717 de los dominios de España»(1). Asi, pues, en el caso de Folch su identificación con el estamento eclesiástico y sus privilegios parecen estar por encima de cualquier otra consideración.

\section{Rasgos sobre "las bibliotecas de Folch de Cardona".}

La siempre precaria situación de la economía regia se tradujo en un verdadero concurso de imaginación por parte de los ministros para aprovechar todas las posibles fuentes de ingresos. De acuerdo con esta dinámica, el 21 de diciembre de 1710 se dispuso, con el correspondiente bene- 
plácito de Robinet, el valimiento de las rentas de la mitra valenciana(82). Apenas 15 días más tarde la defección de Folch se castigaba en el plano personal mediante una Real Cédula que ordenaba la confiscación de todos su bienes personales(83). Su biblioteca polarizó buena parte de la atención de los confiscadores y, posiblemente, cupiera a Macanaz alguna responsabilidad en el énfasis puesto en este asunto pues debia conocerla bien por referencias, bien personalmente al haber sido varias las ocasiones en que visitó el palacio arzobispal.

La noticia de la confiscación, como era de esperar, causó nuevo revuelo en el cabildo metropolitano que «...no pudo impedir que por órdenes de Madrid, y con la aquiescencia de Maquilón, "por no malquistarse con los que le mantenian", se procediese al embargo y posterior envio a la corte de la biblioteca de don Antonio Folch de Cardona». Según el comentario de Planes-que reproduce Pérez Aparicio-se componia de "los libros más selectos y bien encuadernados que se hallavan en España, el número es grande, dicen son para el rey, no sé si aconsejan bien sus validosı(84).

Mucho tiempo después, en un artículo de Francisco Maldonado de Guevara sobre los orígenes de la Biblioteca Nacional, donde se exagera el protagonismo de su antepasado y se pretende justificar la confiscación - siempre desdeñable, añade-en función de haber servido de base a la primera institución de este relieve en España, concluia que:

"Una tarea surge imperativa para la erudición valenciana: la de localizar los dos mil volúmenes cordonianos, la de catalogarlos y describirlos; tarea dificilísima que, acaso, por lo que a la localización se refiere, no pueda nunca llevarse a cabo en toda su entereza. La idea queda expuesta y espero que alentada por el estímulo de restaurar el escenario cultural y espiritual en que se movia la vida religiosa, y también, acaso la vida civil de Valencia en una época muy interesante de su historia»(85).

Desafortunadamente Maldonado, celoso guardián de los tesoros literarios e históricos de su familia, no acierta completamente en todas sus apreciaciones. En primer lugar la participación de Macanaz en la fundación de la Biblioteca Real pronto cedio al mayor empuje de Robinet, incluso por simple imposibilidad física pues, tras una breve estancia en la corte pasaria a la intendencia de Aragón para no regresar a Madrid hasta 
finales de 1712 en compañía del recién liberado marqués de Villena. Por otra parte, la dificilisima tarea de la localización no resulta tan complicada al figurar los inventarios por su nombre en los ficheros de manuscritos de la Biblioteca Nacional. En tercer lugar, como tendremos oportunidad de comprobar, la biblioteca personal de Folch no sirvió de base a la Librería Real al pasar, poco más tarde, a manos de los PP. franciscanos de Palencia. Además, los «dos mil volúmenes cardonianos» en pequeña medida pueden contribuir a la reconstrucción de la vida intelectual valenciana pues desde los 15 hasta los 42 años, en que fue nombrado arzobispo, fray Antonio residió en Castilla y estuvo ligado, en todo caso, a la vida intelectual de Alcalá y de la corte. Desde luego, la localización física de los 2.114 volúmenes, no debería ser complicada en principio al haberse quedado en la Biblioteca Nacional pues se conservan los antiguos libros de registro, pero a partir del momento en que se entregaron a los franciscanos se pierde la pista. Como mera hipótesis, es posible que en parte volviesen a sus estanterías con motivo de la reducción de conventos vacantes y la desamortización, extremo que, hasta el momento nos ha sido imposible determinar.

Como se advierte en el título, en realidad se trataba de las bibliotecas pues además de la personal, el arzobispo se había hecho cargo de la de su tío don José de Cardona, deán y canónigo de la catedral valenciana, que se componia de más de 900 volúmenes, con una importante colección de textos clásicos que en la de fray Antonio brillan por su ausencia. No es difícil deducir que en la mente del prelado estaba, sin duda alguna, el proyecto de formar una gran biblioteca arzobispal lo que explica el que entre 1702 y 1710 comprara en Madrid y Paris libros por un valor superior a las 3.500 libras.

Es evidente que los estudios bibliométricos y biblioteconómicos proporcionan informaciones de sumo interés para la reestructuración de un determinado contexto histórico y que, mediante la elaboración de estadísticas, se clarifican aspectos tales como la difusión e incidencia de corrientes intelectuales, su carácter y procedencia así como los sincronismos-más habitualmente los diacronismos negativos-con los ritmos europeos; los niveles de frecuencia y el volumen de la producción, las técnicas de impresión, encuadernación, vías de comercialización, etc. 
También se ha defendido, y en este sentido las reservas son mayores, la utilización de esta clase de prospecciones para calar y definir los rasgos individuales de su poseedor. Al menos así lo hacía Marañón:

"Los libros que cada cual escoge para su recreo, para su instrucción, incluso para su vanidad, son verdaderas "huellas dactilares del espiritu" que permiten su exacta identificación»(85).

Pese a las indudables condiciones para la penetración psicológica del ilustre erudito, la apreciación resulta excesiva. En la mayoría de los casos se ignora si fueron realmente leídos o no, el conducto por el que llegaron a sus manos, y, en todo caso, si el personaje comprendió, asimiló, participó o repudió a los tirios o a los troyanos. Así se han llegado a deducciones tan sobresalientes como la de que Folch de Cardona era un "hombre muy culto, dueño de una riquísima biblioteca".

El propósito de nuestras notas se sitúa en la perspectiva de señalar algunas de las circunstancias por las que atravesaron las bibliotecas del arzobispo-como prólogo a un pormenorizado y voluminoso análisis de más de seis mil tomos que las componen que actualmente elaboramos algunos miembros del Departamento de Historia Moderna-por lo que reservamos los detalles para una próxima publicación. De ahí que el lector no encuentre prácticamente ninguna referencia explicita a autores ni materias, y sólo a determinadas cuestiones relacionadas con la cronología y las fuentes que utilizamos.

Si el soplo que condujo a la confiscación pudo deberse a Macanaz, la realidad una vez más es que fue Robinet el que desplegó la mayor actividad. A instancias suyas el 16 de marzo de 1711 cursaba Grimaldo órdenes a la Chancillería de Valencia para que pusiera a disposición del Superintendente Rodrigo Caballero la librería del arzobispo. El oidor encargado de la administración de confiscaciones, y sucesor de Macanaz, Damián Cerdá, ordenó a su vez al escribano Víctor de Salafranca levantar testimonio de todos los efectos que se entregaran a Caballero(87). La ejecución, pese al disgusto del cabildo, siguió su curso aunque no con la celeridad que Robinet deseara. A menudo requerirá el $P$. confesor noticias sobre el estado en que se encontraba el asunto del traslado. El mismo dia en que se finalizaba el inventario, el 16 de febrero de 1712, Caballero tranquilizará a su 
impaciente corresponsal al comunicarle que los 6.630 volúmenes, más las colecciones de medallas y mapas, habian sido embaladas en 161 cajas y 13 líos donde se incluian las mismas estanterias, con un peso total de 1.373 arrobas y 25 libras que se dirigian ya en 11 galeras camino de la corte(88).

Si Robinet esperaba contar con esa importante colección pronto hubo de desilusionarse pues de inmediato van a irse sucediendo las reclamaciones de terceros afectados por la medida confiscadora. La primera, la de los PP. franciscanos de Palencia como beneficiarios de los bienes de Folch de Cardona; la segunda la de la heredera del canónigo José Cardona $y$, finalmente los requerimientos por parte de los libreros para que se les satisfaciesen las cuantiosas deudas que el arzobispo habia contraído.

La reclamación de los franciscanos no sólo afectaba a la biblioteca persona/ sino que se hacia extensiva a otros bienes. Por medio del síndico procurador de la Provincia de la Purisima Concepción de Castilla la Vieja don José Viniegra, se solicitó la devolución de todos los bienes que, por ser miembro de la orden, correspondian a la comunidad franciscana. De los laboriosos trámites en la corte se ocupó fray Manuel Rodríguez, que, según sabemos por los informes del bibliotecario Francisco de Roda, anduvo trasteando con su solicitud por los despachos varios años hasta que Robinet dio orden oral para que le fueran entregados los contenidos en el inventario de 1700 . Gracias a este inventario confeccionado por mandato del nuncio don José Arquinto conocemos, al menos los autores, títulos y número de volúmenes de la biblioteca personal de Folch, aunque raramente aparecen el año ni el lugar de la edición. Según la declaración de Celedon Viniegra, ante notario con las correspondientes certificaciones documentales, el futuro arzobispo uhizo, inventario de todos sus bienes con juramento que hizo, y en el expresa, y manifiestamente declara que la Librería que tenia, tocaba, y pertenecía legítimamente al convento de San Francisco de Palencia, la qual desde luego aplicava, para este effecto sacó Bulla de Nuestro Santísimo Padre Ynocencio XII, que expedida en trece de octubre, del año pasado de mil seicientos, y noventa y seis que comienza: Aliar pro parte dilecti fili Antonii de Cardona \&, y que todas las demás Alajas, como Pontificales, Hornamentos, Pectorales, Anillos, Sortijas, Joyas, esmeraldas, Reloxes, y otras pertenecian á esta dha. Provincia por 
haberlas adquirido siendo dicho Religioso, y antes de ser presentado á dicho Arçobispado, y que assí mismo ocho mil, y veinte y dos pesos escudos de plata que declara estar debiendo a dicha Provincia por habérselo dado, y prestado el Síndico General que en aquél tiempo era, con permiso del Rmo. P. Fr. Francisco Herrero Freijo, Provincial que assimismo de ella, procedian de las limosnas que habían juntado para la Beatificación de San Pedro Regalado, y que obraban en su poder, como todo mas largamente consta, y pareçe del dicho inventario....(89).

En el inventario aparecen 2.112 volúmenes tasados por Francisco Laso en 113.902 Rls. de vellón. Cuando fueron a entregarse el 9 de diciembre de 1713 se pudieron encontrar entre los 6.630 tan sólo 1.424 por lo que quedaron pendientes de entrega 668 tomos.

Rodríguez habia subdelegado poderes en el provincial del convento de San Francisco de Valencia, Juan Bautista Bernat, y en Dionisio Mampuesta. Bernat, que había sido el confesor de Folch, informó de que en el palacio arzobispal quedaba una partida de libros en la sala de Sto. Tomás de Villanueva. Ese mismo mes de diciembre, el bibliotecario Andrés Arnaud confeccionó la lista de los volúmenes no encontrados para que fueran entregados a los poderhabientes de los franciscanos en caso de encontrarse entre estos últimos. El 24 de mayo de 1714 Bernat firmó recibo de haber recibido 417 libros sin que pudieran encontrarse los 251 restantes.

El segundo caso al que hicimos referencia tiene menores consecuencias para los fondos bibliográficos de la Biblioteca Real aunque más desfavorables para los económicos. La biblioteca del deán, con una importante colección de textos clásicos editados en Francia, teología, filosofía presenta, frente a la mayor uniformidad temática de la biblioteca de Folch, una mayor dispersión y una inquietud de relieve por los temas de historia natural, matemáticos y de "curiosidades" científicas. Este es un documento de singular importancia que sí está en relación directa con la vida intelectual valenciana y, sobre todo, con los novatores como se trasluce en la relativa abundancia de temas médicos. La heredera del deán José Cardona presentó tercería ante el Real Acuerdo a raiz de la confiscación de la biblioteca que, al parecer, el arzobispo se habia llevado a casa sin llegar a satisfacer su importe. Pero a doña Maria no le interesaba tanto la bilbiote- 
ca como su traducción pecuniaria. Nombrados tasadores por las partes interesadas - Juan Baeza y Luis Lamarca-se apreció finalmante el 16 de agosto de 1712 en 1.810 libras y 17 sueldos que, suponemos, llegaron a hacerse efectivos con el tiempo pues contaba con la opinión favorable de Cerdá y del mismo Caballero.

Entre las virtudes que Fuster destaca en la personalidad del arzobispo están las de que "manifestó ser doctísimo, espléndido, justo, magnánimo, acérrimo defensor de los derechos y jurisdicciones de su Mitra, de la inmunidad eclesiástica...»(90). Lógicamente no se encontraba la de buen pagador, lo que, como es sabido no era sino añadir brillo a la honra. Otra opinión debian tener los libreros Anisson de París y Madrid y Francisco Laso pues elevaron sendas peticiones para que se les abonasen las deudas contraídas con ellos en los últimos años. Laso presentó pagarés, firmados por el propio Folch de Cardona en 19 de sepriembre de 1700, por valor de 78.240 Rls. Además, en septiembre de 1713 adjuntaba una factura detallada de uno de los últimos encargos que le hizo el arzobispo antes de su defección pues lleva fecha de 8 de febrero de 1710. También quedaban pendientes los pagos a los Anisson, cuyo detalle conocemos también, y que están fechadas el 15 de julio de 1702 y el 25 de febrero de 1705. De 1708 se conserva un reconocimiento de deuda por parte del arzobispo por otra cantidad de 6.354 Rls. de vellón.

El bibliotecario Francisco de Roda, en un informe elaborado para el $P$. Vermudez en 1725 con motivo de haberse reavivado las reclamaciones de los franciscanos sobre los bienes de Folch, comentaba que el P. Robinet "las satisfizo en pago de los 5.206 tomos que quedaron en esta R. Bibliotheca y no consta en ella, las cantidades, que entregó a los dhos Libreros, y puede ser que entre los papeles del dho Pe Dr. Pedro Robinet se halle razón de estas cantidades. Esto en quanto se me ofrece que decir sobre este assumpto....(191). 


\section{NOTAS:}

(1) DOMINGUEZ ORTIZ, A. Sociedad y Estado en el S. XVIII español. Barcelona. 1976, p. 116.

(2) La universidad jesuita de Cervera (1716) será una de las pocas excepciones en este campo. No obstante, resulta muy significativa la intervención del protector Juan Curiel para evitar la «peligrosa" salida de los estudiantes catalanes a Francia y aumentar el control sobre el acceso de miembros ajenos a la nobleza. RUBIO BORRAS, M., Historia de la Universidad de Cervera. Barcelona, 1915. ORTIZ, Op. cit. p. 109. Sobre el deterioro de la institución universitaria en el siglo XVII y su intrumentalización regalista, KAGAN, R. L. "Las Universidades en Castilla, 1500-1700" en ELLIOT, J. H. Poder y sociedad en la España de los Austrias" Barcelona, 1982, pp. 57-89; y Universidad y Sociedad en la España Moderna, Madrid, 1981.

(3) DOMINGUEZ, Op. cit., p. 116.

(4) KAMEN, H. La Guerra de Sucesión en España, 1700-1715. Barcelona, 1974. p. 345.

(5) UBILLA Y MEDINA, A. Marqués de RIBAS. Succesión de España: Diario de sus viages desde Versalles... Madrid, 1704. Un estudio del texto en GOMEZ DE LA SERNA. G. Los viajeros de la llustración. Madrid, 1974. Sobre Felipe $V$ hay substanciosas anécdotas en FERRER DEL RIO, A. Historia del reinado de Carlos III en España, Madrid, 1856, 4 vols.; t. 1, pp. 123 y ss. DANVILA Y COLLADO, M. en los 6 vols., correspondientes al Reinado de Carlos III, especialmente el tomo I que trata de la infancia de Carlos III. BAUDRILLART, A. Philipe $V$ et la cour de France. Paris, 1860. E vols. T. I, pp. 109 y ss. Maintenont-Harcourt, 3-XII-1700.

(6) Sobre el "bibliotafiondel Escorial, el fracaso de las intenciones de Paez de Castro y las opiniones de Antonio Agustín y Zurita, GIL. FERNANDEZ, L. Panorama social del humanismo español (1500-1800). Madrid, 1981. pp. 704-724 y en particular p. 711. cit. 22 y 721 cit. 45.

(7) MALdONADO MACANAZ, J. Melchor de Macanaz. Testamento Politico. Pedimento Fiscal. Madrid, 1972. pp. 44-45. También en MALDONADO DE GUEVARA, F. "Los orígenes de la Biblioteca Nacional" en Revista Valenciana de Filologia, t. I, $n .^{\circ} 2$, abril-junio. Valencia (1951) p. 154.

(8) BELANDO, N. J. Historia Civil de España. Sucesos de guerra y Tratados de Paz, desde el año 1700 hasta el de 1733. 3 vols. Madrid, 1740-43, t. III, pp. 56 y ss. KAMEN, H. Op. cit. p. 346 , ก. 30 .

(9) ABELLAN, J. L. Historia critica del pensamiento español, t. III, pp. 355-376.

(10) MALDONADO MACANAZ, Op. cit. 45-46. MALDONADO DE GUEVARA, Op. cit. 155.

(11) Fue el canónigo de la doctoral de Segovia, don Juan Manuel de Santander, bibliotecario mayor entre 1751 y 1761 , y desde esa fecha el primer director que no era confesor real, quien "tomó con gran entusiasmo esta empresa, y en 1783 ya pudo ofrecer al rey el valor de un millón y medio de reales que representaban las pensiones y matrices en número de 13.000 , las impresiones hechas y el papel para otras". Más tarde se hizo cargo el valenciano Benito Monfort. Apud. RODRIGUEZ MARIN, F. Guia historica y descriptiva de los Archivos, Bibliotecas y Museos Arqueológicos de España... Madrid, 1916.

(12) Catálogos de las obras de Macanaz en MALDONADO MACANAZ, Op. cit. pp. 15-38 y KAMEN. Op. cit. Apéndice 7, pp. 442-445. 
(13) El resultado de la Guerra supuso una nueva pulsión y aceleración del proceso en este sentido: centralización, anulación de privilegios forales, nuevo sistema impositivo, absorción de funciones hasta entonces reservadas a los municipios, recortes en la práctica a la jurisdicción eclesiástica,...

(14) SAINT SIMON, Marqués de. Memorias. Citamos por la versión abreviada de BERGES, C. Barcelona, 1982, P. 101.

(15) FERNANDEZ POMAR, J. M. «드 fondo clásico de la Biblioteca Nacional de Madrid y el Renacimiento españoln. SIMPOSIO SOBRE LA ANTIGÜEDAD CLASICA. Madrid, 1969. pp. 71-93. cit. p. 75.

(16) PONCE DE LEON FREYRE, E. Guia del lector de la Biblioteca Nacional. Madrid, 1949, p. 10 .

(17) MARTIN GAITE, Op. cit. p. 304.

(18) Apud. idem. 326.

(19) SAINT-SIMON. Op. cit. p. 325.

(20) Idem. pp. 90-91.

(21) MESTRE SANCHIS, A. Despotismo e liustración en España, Barcelona, 1976, p. 108.

(22) MESTRE. Idem. pp. 110-112. Historia, fueros y actitudes politicas. Mayans y la historiografia del XVIII. Valencia, 1970. pp. 41 y ss.

(23) RODRIGUEZ MARIN. Op. cit. p. 7.

(24) Novss. Recop. Lib. VIII, tit. XIX, ley I. R. D.-2-I-1976.

(25) Idem.

(26) PONCE DE LEON. Op. cit. p. 12.

(27) «Fundación, y estados de la Libreria de el Rey Nuestro Señor D. Phelipe $V$ Rey de Españan Año 1716. En Madrid en la Oficina de Francisco del Hierro. Fol. 14 págs. Citado por LOPEZ DE VALDEMORO QUESADA, Conde de las Navas. Catálogo de la Real Biblioteca Autores de Historia. Madrid, 1910. Se reproducen en RODRIGUEZ MARIN, Op. cit. pp. 4-6.

(28) Novss. Recop. Lib. VIII, tit. XX, ley XXXVI. R. D. 26-VI-1716. PONCE DE LEON, Op. cit. p. 12.

(29) La petición rebasa con creces las meras reivindicaciones profesionales. Véase el significado profundo de la anécdota en MARAVALL, J. A. Poder, honor y élites en el siglo XVII. Madrid, 1979, pp. 41.

(30) Idem. n. 24.

(31) Idem. n. 28.

(32) Novss. Recop. Liv. VIII, tit. XIX, ley 2. R. D. 11-XII-1761. "Observancia de las nuevas constituciones...n; el privilegio original en Idem. Lib. VIII tit. XIV, ley. IV.

(33) PONCE DE LEON. Op. cit. p. 15.

(34) Idem. ก. 33.

(35) PONCE DE LEON da la fecha de 1819. PAZ Y MELIA, A. La cuestión de las Bibliotecas Nacionales y la difusión de la cultura. Separata de la R. A. B. M., Madrid, 1911, p. 12 no concuerda con él.

(36) MALDONADO MACANAZ. Op. cit. p. 154. KAMEN. Op. cit. p. 345-346. 
(37) RODRIGUEZ MARIN. Op. cit. pp. 3-4. El inventario en B. N. Mss. 18.791.

(38) Idem., p. 27. Sobre el deán Marti y Medinaceli, MESTRE. Historia, fueros... p. 34.

(39) MALTES, J. B. y LOPEZ, L. Ilice Ilustrada, Alicante, 1907. p. 416.

(40) RODRIGUEZ MARIN, Op. cit., pp. 27-28.

(41) Para las confiscaciones en general vid. KAMEN, Op. cit. El caso de las confiscaciones en la gobernación de Alicante en PRADELLS NADAL, J. Del centralismo al foralismo. Alicante 1700-1715. Alicante, 1984.

(42) A. H. N. Estado. leg. 2.973.

(43) Citas anteriores y PARDO Y MANUEL DE VILLENA, A. El Marqués de Rafa/ y el levantamiento de Orihuela en la Guerra de Sucesion. Madrid, 1910. Apéndice n. ${ }^{\circ}$ 5, pp. 117-122.

(44) A. H. N. Estado, leg. 380. Cartas de 5 del III y 29 del IV de 1710

(45) Idem. ก. 44.

(46) KAMEN, Op. cit. pp. 344, 358 y 363.

(47) A. H. N. Estado. leg. 331. Bádenes-Grimaldo, 22-V-1708. MIÑANA, J. M. "De Bello Rustico Valentino" en Revue Hispanique, LV (1922), pp. 447-448.

(48) MALDONADO MACANAZ. Op. cit. p. 190.

(49) PEREZ APARICIO, C. «EI clero valenciano a principios del siglo XVIII; La cuestión Sucesoria" en Estudios de Historia de Valencia. Valencia (1978), pp. 247-278. Sobre la destrucción de la documentación arzobispal, p. 253 n. 6.

(50) BACCALLAR Y SANNA, V., Marqués de San Felipe. Comentarios de la Guerra de España e Historia de su Rey Felipe V, el Animoso. Madrid, 1957. pp. 100, 206-7, 309 y especialmente p. 261.

(51) FUSTER, J. P. Biblioteca Valenciana, t. II, pp. 14-16.

(52) Sobre las peculiaridades de la "bastardia hispánica» vid. SAINT-SIMON, Op. cit. p. 95.

(53) PEREZ APARICIO. Op. cit. p. 252.

(54) Idem. pp. 251-262.

(55) KAMEN, H. La España de Carlos II. Barcelona, 1981, pp. 39-41.

(56) Una sintesis en MESTRE, A. dentro de la Historia de la lglesia en España, Vol. IV, del P. GARCIA VILLOSLADA. Madrid, 1979, pp. 590-91.

(57) PEREZ APARICIO. Op. cit.

(58) Apud. PEREZ APARICIO. Op. cit. p. 253. Carta de 3 de junio de 1704.

(59) Idem. p. 256.

(60) Idem. p. 256 notas n. ${ }^{\circ} 13$ y 14.

(61) SAN FELIPE. Op. cit. p. 206-7 y 261.

(62) A. H. N. Estado, leg. 265. Villagarcia-Grimaldo, 25-VIII-7.705.

(63) Apud. PEREZ APARICIO. Op. cit. p. 254.

(64) A. H. N. Estado. leg. 279. Folch-Grimaldo. 27-X-1705.

(65) Idem. 1-XII-1705.

(66) MIÑANA, Op. cit. 1-7, pp. 481-482.

(67) Idem. I-7. pp. 481-482. 
(68) ORTI, J. Reparos Criticos,... en Semanario Erudito de Valladares. Madrid, 1788, vol. XVIII. En particular el punto segundo «Donde se refiere lo sucedido en Valencia en la próxima pasada guerra, hasta que volvió al dominio del Rey y se verá cuanto en su daño calló el Padre Miñana y erró el Marqués", pp. 98-148.

(69) "No hubo un reformismo religioso felipino, sino un mayor rigor en la defensa de las regalías, en sus aspectos jurisdiccionales y económicos. El rey aspiraba a nombrar a todos a la mayor parte de las plazas eclesiásticas en calidad de patrono (Patronato Regio Universal) como ya venía haciéndolo en las Indias, y a la vez pretendia obtener del clero la máxima tributación, y la represión del extendido fraude fiscal». DOMINGUEZ, Op. cit. pp. 96-97.

(70) Novss. Recop. Lib. III, tit. 3. ley 1.R.D. 29 de junio de 1707.

(71) PESET, M. "Apuntes sobre la Iglesia Valenciana en los años de la Nueva Planta" Annales Valentinos. Valencia (1972), n. ${ }^{\circ}$ 2, pp. 245-58. p. 249.

(72) Idem. p. 247.

(73) R. D. 27-XI-1707, reproducido en parte por MARTIN GAITE. Op. cit. 124 y ss.

(75) EI R. D. de 27 de noviembre y el bando de Macanaz los reproduce parcialmente MARTIN GAITE, Op. cit., pp. 125 y ss. PESET. Op. cit. nota 9 de p. 249.

(76) Las informaciones proceden de MARTIN GAITE, PESET y KAMEN además de A. H. N. Estado, leg. 350 "instruzion que a de observar el Sr. Arzobispo.... VOLTES BOU, P. La Guerra de Sucesión en Valencia. Valencia, 1964. Apéndice documental, pp. 99-105 y 185-190 y de mi propia tesis de licenciatura, ya citada.

(77) Sobre la excomunión de Macanaz, ORTI Reparos críticos... p. 182-86.

(78) SAN FELIPE. Op. cit. pp. 206-207.

(79) MALTES y LOPEZ. Illice Ilustrada... p. 386.

(80) ORTI. Op. cit. pp. 186-87.

(81) FUSTER, Op. cit. p. 16.

(82) KAMEN. Op. cit. p. 357.

(83) Apud. PESET. Op. cit. p. 248.

(84) Apud. PEREZ APARICIO. Op. cit. p. 274.

(85) MALDONADO DE GUEVARA, Op. cit. p. 156-57.

(86) MARAÑON, G. «La biblioteca del Conde Duquen. B. R. A. H. t. 107. (1937) pp. 673-677. Además daba unos consejos sobre buen saber estar: «El hombre de una cierta importancia social debe recibir siempre en su libreria, modesta o magnifica, porque nada da, al que va a visitarle, idea más cierta de lo que es y de sus posibles reacciones». p. 677.

(87) "Testimonio de los libros, estantes, y demás adherentes que contenia la Libreria de Rvdo. Arçobispo de Valencian por Victor de Salafranca, en Valencia a 16 de febrero de 1712. B. N. Mss. 8.373. ff. 45-183.

(88) A. H. N. Estado. leg. 412. Caballero-Grimaldo. 16-11-1712.

(89) B. N. Mss, 8.397 . fol. 20 y ss.

(90) FUSTER, Op. cit. p. 16.

(91) "Informe que dió al P. Confesor sobre la libreria del Arzobispo de Valencia Fr. Antonio Folch de Cardona». B. N. Mss. 8.397. 